\title{
Economic crisis and the coping strategies of indigenous automobile entrepreneurs in northern Nigeria, | 983-20|4
}

\begin{abstract}
The Nigerian economic crisis of the early 1980 s and the stabilization policies that were introduced to contain it have triggered inflation in the country leading to deplorable socio-economic conditions. Automobile industry is one of many sectors of the country's economy that were negatively affected by the economic crisis. In response to the situation the indigenous automobile businessmen began to use new strategies to survive the downtrend in the automobile market. Apart from shifting to Second-hand automobile trade, the businessmen have also introduced new marketing strategies such as kakara (trade in) and Jagwal (trade on) in order to survive the challenges posed by expatriates' automobile companies mostly from China and Korea. With these strategies, the traders not only maintain their prominence in the automobile market but also open up other areas of economic ventures such as second-hand spare parts market, used vehicle market (Kasuwar tabajiki), waste market (Kasuwar gongoni) among other strategies. The main focus of this paper is to look at the effects of the long term economic recession and the economic stabilization programmes of the 1980 s on the automobile market and the response of indigenous automobile traders to devise a variety of coping strategies to overcome the crisis. What these strategies are and their implications on the automobile market and society constitute the subject of the paper.
\end{abstract}

Volume 3 Issue 6 - 2019

\author{
Abubakar Sama'ila \\ Department of History, Usmanu Danfodiyo University, Nigeria \\ Correspondence: Abubakar Sama'ila, PhD, Department of \\ History, Usmanu Danfodiyo University, Sokoto, Nigeria, Tel \\ +234-809 462 9949, +234-810 0590300 , \\ Email abubakarsmail400@gmail.com, abujbo28@yahoo.com
}

Received: July 25, 2019 | Published: November 19, 2019

\section{Introduction}

Within the last four decades, more than ever before, automobile business especially in used-vehicles has become a booming reality in Nigeria. The period between 1983 and 2014 constitute an important landmark in the development of second-hand or used vehicle market in Nigeria. The year 1983 witnessed unprecedented collapse in the manufacturing output in Nigeria including automobile production. The massive importation of second-hand vehicles since then resulted to series of economic measures culminating to New Automobile Policy in 2014. In 2016, the Federal government has also come up with the new auto policy (banning importation of second-hand cars tokunbo across the country's land borders). The policy banned the importation of Second-hand or fairly used vehicles into the country. However, the impact of such measures were short lived, partly because the traders have consistently and persistently been adopting strategies to keep the market going. What these strategies are and how they contribute to the expansion of second-hand vehicle market in Nigeria, constitute the subject of this paper. The paper sought to maintain that the impact of the economic troubled years of the eighties coupled with dwindling oil price in the World market have plunged the country into economic crisis that affected socio-economic conditions of Nigerians. It thus begins by examining the circumstances leading to the rise of secondhand vehicles market especially with the economic problems of the early 1980s. Since many Nigerians were unable to afford new vehicles because of the economic hardship, the second-hand market provides alternative options.

The main reason for the boom in tokunbo vehicle market in Nigeria was related to liberalization reforms of Structural Adjustment Program (SAP) when local currencies were devalued and consequently consumer goods became too expensive for most Nigerians. This led to the rise of poverty profile in the country and consequently greater participation in the Second-hand market. The country's poverty profile has risen over the years from 27.2 per cent in 1980 to 65 per cent in 1996. ${ }^{1}$ The country's north-west zone come second to north-east in the poverty figures rate. The north-west zone has 37.7 in 1980, 52.1 in 1985, 36.5 in 1992, 77.2 in 1996 and 71.2 per cent in 2004 (Ibid). By these statistics the zone falls within the United Nations definition for a Least Developed Country or (LDC) although the country itself is classified as Low Income (LIC). The rising costs of locally assembled new brand vehicles brought about by the depressed economy have led to the turnaround for the Second-hand or fairly used ones. Potential consumers of locally made vehicles could no longer afford to buy new vehicles and therefore began to patronize second-hand vehicles market. Consequently, Nigeria's automobile assembling industry had substantially declined by the early 1990s. Tokunbo automobile therefore, provide the alternative with comparable utility and symbolic value for consumers across class boundaries. So alarming that, about 95 per cent of the vehicles in Nigeria are imported second hand ones. ${ }^{2}$ In Northern Nigeria, the expansion has also come along with new marketing strategies, initiated by the traders especially the kakara and Jagwal in order to survive the challenges posed by expatriates automobile companies mostly from China and Korea. With these strategies, the second-hand vehicle traders continued to consolidate the strength of the market and even open up other areas of economic ventures such as spare parts market and used vehicle market (Kasuwar tabajiki) as well as waste market (Kasuwar gongoni) among other strategies. This paper examines these strategies and how they shape and consolidate the trade in used-vehicles in the period between eighties and Nineties.

\section{Conceptual clarification}

The word automobile used in this work refers to "motor vehicles" primarily passenger and commercial vehicles. The usage is meant to exclude a number of closely related products such as motor cycles, tractors and other forms of motorized transport. Those excluded from 
this conceptual definition remain excluded from the scope of this paper. Similarly, the word 'Tokunbo' as used in the paper refers to 'the second-hand vehicle imported from abroad'. To be a 'tokunbo' a vehicle must be a fairly used vehicle shipped from Europe, the Americas or Far East. However, for clarification, an internally used vehicle in Nigeria displayed for sale is not 'tokunbo vehicle', rather, it is a 'used vehicle'. The term tokunbo is a Yoruba language which means 'the used goods coming from overseas'. ${ }^{2-4}$ 'Tokunbo' literally means 'from across the seas'. The use of the term began as a name for Yoruba children conceived or born in western nations, especially in the colonial period up to the 1990s. But the term tokunbo is now generally used for imported second-hand goods. In this paper the word Tokunbo is used to refer to 'second hand vehicles imported from overseas to Nigeria or across the country's land borders.

Other concepts used in the paper which requires clarification is Kakara and Jagwal. Kakara is a Hausa word indicating that a person wants to replace a particular item usually used one or of low standard with new or another superior version. ${ }^{5}$ Kakara (trade in) means to give an old or used item, especially a vehicle, in part payment for a new one. The practice of kakara has recently gained ground because of the expansion recorded in tokunbo vehicles business in the country. Another related strategy similar to kakara which is also used by the tokunbo vehicle traders is Jagwal (trade on) Whereas, in Kakara (trade in) the owner of the disposed vehicle pays the remaining balance to the seller to obtain new one, in Jagwal the reverse is the case. The owner of the vehicle, for one reason or the other decides to change his vehicle with a lower version and get in turn the balance over the price of the lower version he is purchasing. ${ }^{6}$ Jagwal is very rare in tokunbo vehicle market and it is more pronounced only where an owner is in daring need of money. The reasons for the adoption of such marketing strategies has to be found in the efforts of those indigenous automobile traders in northern Nigeria who were nearly kicked out of market in the early eighties. To situate the whole issue into context a brief overview of their business career is necessary.

\section{Overview of automobile trade in northern Nigeria}

The trade in motor vehicles became significant by about the 1940s when records concerning the trade began to be kept. However, first motor vehicles, two in number arrived in Lagos in $1902 .^{7}$ In 1937, the motor vehicles stock has increased to 507 and the figures increased to 1,878 vehicles in 1946 . By the 1950 s the business had become an important economic activity that involved hundreds of people. The earliest people who began the importation of motor vehicles include; Alhaji Sani Marshal who started as truck driver, but after saving some capital he established his own transport business in 1949. By the early 1950s he had a fleet of lorries running between Lagos, Kano and other parts of Northern Nigeria. ${ }^{8}$ Similarly, Alhassan Dantata diversified into transport business from Kola nuts trade around the same time and so did other businessmen such as Alhaji Abubakar Turaki, Alhaji Garba Dankawu, Alhaji Inuwa Wada and Alhaji Hassan Nawake. Also, when the Igbo entrepreneurs left Kano in the middle of the 1960s as a result of the civil war, Hausa transport businessmen establish their monopoly of this sector. ${ }^{9}$ In fact by 1980 , there were 61 large scale transport businessmen with a fleet of Lorries in Kano. Consequent upon this expansion in transport sector, the passenger vehicles had recorded annual growth rate of 40.38 per cent between 1966 and $1978 .^{10-12}$ Similarly, of the 238,000 commercial vehicles imported into the country in 1973, Kano state entrepreneurs and Kano state government purchased 44,000. ${ }^{13}$ Furthermore, between 1973 and 1979 a total of 112,085 vehicles were also registered in Kano (Ibid).

Similarly, in the former Sokoto state, some few businessmen joined the vehicle importation trade since 1950s. The auto business was said to have started in Sokoto by Alhaji Ummaru Dantama who was the first businessman to begin selling motor cycles and later vehicles in the middle of the $1950 \mathrm{~s} .{ }^{14,15} \mathrm{He}$ was also the sole agent of the automobile pioneer companies in the zone which include; Leventis, UTC, SCOA, Leyland, Styer, PAN, and Toyota. Leventis initially brought Honda and Mercedes, while UTC imports Mandillas, Incass and Santana among others. Dantama was also said to visit more than twenty countries in different parts of the world including Germany, United Kingdom, France, Japan, Korea and Russia in the course of doing automobile business. According to him, the most popular brand during the 1950s and 1960s was the Peugeot saloon followed by Billford kitika and the Lorry Akori-kura. The predominance of these vehicles in the country during the period was due to, in part, availability of repairmen (local mechanics) who were conversant with the complexities of these model's engines. Durability of the models was also another factor for the popularity of Peugeot which can take as long as six month without servicing.

During the period of booming automobile importation into the country, these businessmen were given free hand and favorable licenses to import as many as they wish into the Nigerian market. The fact that, the economy was buoyant means that the exchange capacity of the Naira was very strong and can compete favorably with any other international currency. This fact is reflected in the event that in the Middle of the 1970s Alhaji Dantama went to Germany with N500,000 and bought twenty two new brand vehicles of Suberu, Honda and Toyota models. In fact the money covers not only the price of the vehicles but also the cost of clearance and other Port tariffs. The price of some of these vehicles during the period range from N2600 to N6000. The sample of the price include; Toyota: Corrolla, N2600, Coronna, N5000, and Toyota Hilux, N4500; Honda, between N5500-N6000; Volkswagen; N2500-N2600; Peugeot, N4500-N5500; Volvo, N5000-N6000; Belford, N7000 and the Nissan cost N5500 Naira. Among his close associates in the business since the 1960s are; Alhaji Aminu Dantata Kano, Malam Isyaku Rabi'u Kano, Alhaji Yusuf Danhausa Gusau, Alhaji Haliru Abdullahi Kafur Katsina, Alhaji Yuguda Gusau, Late Alhaji Ibrahim Madugu Nabakon Wayya Kano, Alhaji Haruna Aliyu Kano, Alhaji Ya'U Danbatta Kano, Alhaji Abdullahi Jajere Kaduna and Alhaji Abdullahi Dudu Kaduna. Some of them who are alive have switched to tokunbo vehicles business when the new automobile market collapsed while others switched to other business ventures.

Another important personality in the automobile trade during the 1960s is Alhaji Balarabe Mainasara, Kwamberu. He was the owner of National Standard Motors, Dogon-Daji House, Sokoto, before his demise in November, 2013. He started the automobile business in 1960 as an agent and later auctioneer for the Peugeot Automobile in 1970. He was the first person to start selling second-hand vehicles which he use to display in the outskirt of the city around Birnin-kebbi road, Sokoto. That gave him an ample opportunity to become the first chairman of National Motor Dealers Association, Sokoto Branch. Among his close associates in the business since the 1960s are; Alhaji Aminu Dantata Kano, Malam Isyaku Rabi'u Kano and Alhaji Ummaru Dantama, Sokoto. One interesting thing about these automobile businessmen is that most of them switched to second-hand or Tokunbo vehicles trade in the 1980s when Nigerian automobile industry collapsed. 


\section{Economic crisis, reforms and Nigerian automobile industry}

The period since the beginning of the $1980 \mathrm{~s}$, has been marked by steadily deepening economic crisis which has had far reaching consequences for various sectors of the Nigerian economy, most especially the manufacturing sector. ${ }^{16}$ Prior to the crisis, the Nigerian economy enjoyed almost a decade of unprecedented revenue boom arising from the petroleum price increases of the 1970s. With output of around two million barrels a day, the country is the leading producer in Africa, the sixth-largest within the Petroleum Exporting Countries (OPEC) and the tenth largest in the world..$^{17}$ In the seventies, Nigeria enjoyed economic boom evident by growing industrial sector and output, rising per capital national income, a respectable payment position and increased inflow of foreign investments, among other indicators. However, by the early 1980s, the Nigerian economic boom came to a halt by a deepening economic crisis which has rapidly engulfed its manufacturing industry among several other sectors of the economy. ${ }^{18}$ The crisis resulted in the immediate domestic context for the adoption by the Nigerian state of Structural Adjustment Program sponsored by the International Monetary Fund (IMF) and the World Bank. Since its creation, far from providing solutions, it has become part and parcel of the dynamics of the country's economic crisis, exacerbating existing pre-adjustment problems. The impact of Structural Adjustment Program was felt more on the industrial sector which has both forward and backward linkages with other sectors of the economy. ${ }^{19,20}$

The adoption of Structural Adjustment Program and the various cost rationalization measures, including devaluation of the Naira as well as the review of tariff structure under General Ibrahim Badamasi Babangida administration did not actually solve the problems of manufacturing companies. The consequence of the devaluation of the Naira for example increased import costs. The amendments in tariffs in 1986 and 1988 compounded the problems of manufacturers as many companies reduced their production in order to adjust to the prevailing situation. ${ }^{16}$ Most of these companies were heavily dependent on imported inputs. In fact many of these companies had to come to terms with producing in an economy that was in deep crisis. As one of its major objectives, SAP was put in place to restructure and diversify the country's economy in order to reduce dependence on oil sector and imports. By early 1980s following the collapsed of the world oil market, the ability of the Nigerian state to continue to finance the import needs of the industries was severely undermined as its foreign exchange earnings were drastically reduced. The state's oil revenue fell from 10 billion Naira in 1979 to 5,161 billion in 1982, at a time when raw materials and capital goods import requirement of industry was put above 5.7 billion and the total import requirement of the entire economy exceeded 13 billion. ${ }^{18}$ The decline resulting from the collapse of the world oil market brought about structural imbalances in the import-substitution sector and led to a deepening crisis in the industries.

As one of its major objectives SAP was put in place to restructure and diversify the Nigerian economy in order to reduce the country's dependence on oil sector and imports. Sequel to this was the adoption of realistic exchange rate policy through the establishment of Second-Tier Foreign Exchange Market (SFEM). The background for this reform has to do with the structural contradiction in the country's dependent economy. The exchange rate management strategy otherwise known as Second Tier Foreign Exchange Market
(SFEM) was an exchange rate management strategy introduced under Structural Adjustment Program (SAP) and sustained with some modifications of procedures. The oil boom of the 1970s deepened the structure of Nigeria's import-dependent industrialization. Many local and foreign business interest eager to take advantage of Nigeria's growing domestic market established many more manufacturing plants to produce light consumer goods using inputs imported from foreign sources. Consequently, when a dramatic drop occurred in the international price of oil in the early 1980s as a result of the glut in the world market, the corresponding fall in Nigeria's oil triggered an unprecedented crisis of immense dimension in the economy. ${ }^{17}$ The immense consequence of this development on manufacturing sector as many factories folded up in the face of an acute shortage of an inputs, particularly spare parts and raw materials. It had been reported for instance, that in the period between 1983 and 1985 about 50per cent of the factories operating in the country collapsed outright. ${ }^{18}$

The devaluation of the Naira during the SAP year seriously affected both the vehicle plants and the vehicle dealers. This was inevitable since vehicles in Nigeria, whether imported whole unit or assembled from imported CKDs, depend on foreign exchange. This meant that both the vehicle assembly plants and car dealers found themselves virtually out of the market. ${ }^{21}$ The devaluation escalated the price of vehicles by between 200 and 400 per cent. ${ }^{22}$ This was true of imported consumer items as well as those produced locally. What this meant is that SAP reduced the real income of the Nigerian wage earner four-fold which was made worse by the wage freeze, which came with SAP. By 1987, Nigeria was removed from the list of middle income nations and re-classified as a low income one. ${ }^{23}$

The difficulty in sustaining the automobile industry in the country which was not only capital intensive but export dependent, manifested clearly when the exchange rate of the Nigerian currency, the Naira, continued to fall. For example, it fell from $\$ 1.00$ to N88.00 in 1994, $\$ 1.00$ to N115.0 in year 2000 and $\$ 1.00$ to N120 in year 2005. ${ }^{22}$ became difficult to import vehicles and spare parts and when they were imported at all cost, they were done at a much prohibited cost. Similarly, the cost of locally manufactured vehicles went up and some of the vehicle-manufacturing companies folded up. In fact, the period between 1985 and 1998 was particularly difficult for Nigerians as the standard of living became very low. Hence buying of vehicles for whatever purposes was not considered as being in the priority. New vehicle registration therefore fell drastically in the country while many old vehicles quit the road. For example, vehicles declined from 700,000 vehicles in $1983 / 84$ to under 500,000 in $1987 .{ }^{24}$ Unfortunately, as the vehicle stock in the country continued to decline, population continued to rise, while disposable income continued to fall. The changing pattern of price rising after SAP had been more dramatic in automobile industry than in any other given sector. Cars for instance, are commodities whose prices have undergone volatile changes during the eighties. For instance, the price of VW Beetle in 1975 was sold for N2,955 but had risen consistently from then to N6,662 in 1985 , an increase of about 190 per cent. ${ }^{21}$

The price variations within these periods are even minimal compared to how suddenly prices jumped after SAP was put in place in 1986. This vary model's price went up from N9,000 in march 1986 to N19,780 in October 1986, just a month after SAP and by February 1987 it had gone up to N26,556 and to N31,948 by December $1987 .{ }^{23}$ This trend is almost the same with other plants. The prices for the various brands of Peugeot cars rose between $200 \%$ and $194.11 \%$, from 
the pre-SAP price of $\mathrm{N} 10,000$ to N17,000 to N30,000 to N50,000 in $1986 .{ }^{23}$ The popular Peugeot 504 GR, which in 1981 used to sell for N6, 691 was already asking for a show room price of N33,432 by January 1987 (Ibid). Consequently, there was dropping in the number of both private and passenger vehicles since 1986 due to fall in the purchasing power of the public. The public, in reacting to the high cost of buying new vehicles, resulted to buying used vehicles (Tokunbo). Thus, used buses, and cars were imported from overseas and people started buying them.

\section{Marketing strategy of indigenous automobile traders}

\section{Trade in damaged /sub-standard tokunbo vehicles from overseas}

The trade in sub-standard or damaged vehicles became widespread in Nigeria for the past four decades. Since 1980 automobile traders have ventured into importation of auctioned, demurrage (holding of a cargo or carrier because of the loading or uploading delay) or damaged vehicles from Lome and Cotonou ports into Nigeria. ${ }^{25}$ Most of the traders do that in order to cut expenses and because it brings more profit. Those who specialized in it wait for two to four weeks for its arrival. The increase in the trade in damaged vehicles was due to the easy flow of these vehicles from Europe and the manner in which one can easily disposed his damaged vehicle and get new one from the company. Although a law was passed in Europe to stop the export of 'the end of life vehicles', the export of these vehicles continued in Africa at an alarming scale. Cotonou and Lagos ports are very popular for off loading large number of damaged vehicles. Business information on this type of trade is highly restricted and protected.

Since the used automobile market serves to provide consumers with a more continuous and wider set of consumption choices the damaged vehicles demand increased hand in hand with diminishing profit margin in the used vehicles market. Consequently, current owners of the old vehicles are also able to trade their automobiles for the purchase of new repaired ones at a lower net cost. In the process other consumers with different preferences or lower incomes are offered a preferable alternative to buying the tokunbo one. The damaged Tokunbo vehicles have generally been described as cheaper since they are obtained with little amount of money although they are labor extensive. ${ }^{26}$ Furthermore, since they are close to the age of their obsolescence, the damaged vehicles are less efficient and less reliable therefore does not attract many customers in the major vehicles market such as Abuja, Kaduna, and Lagos e.t.c. However, people mostly patronize these vehicles in some cities where there are low income. Places like Sokoto, Gusau and Katsina are some major markets for damaged tokunbo vehicles since they are considered cheaper and simple to maintain. But most likely the market for damaged vehicles expanded in these areas due to the fact that, the cost of mechanical maintenance is cheaper generally compared to other parts of the country ${ }^{6}$

On a final note, the damaged or substandard tokunbo automobiles are dismantled in parts to complement the spare parts that are sourced from the discarded vehicles from the developed countries. This has not only brought a relief to the huge demand for spare parts in the country, but also created a large 'waste market' employing substantial population of youths. Virtually all parts of the popular brands are available in the spare parts market. However, parts of more recent models are scarcer than those for the old models. Unlike other goods, tokunbo spare parts are not necessarily cheaper than the available new spare parts particularly the substandard ones popularly called China or Taiwan. Therefore, in terms of preferred purchases, tokunbo spare parts are considered first even when the new ones are available. This is because of the substandard nature of most new automobile spare parts that are available in the market.

\section{Kakara (trade in) and Jagwal (trade on)}

Due to the very nature of tokunbo vehicle business as capital intensive, the marketers are using varying marketing strategies to get customers. The most outstanding marketing strategy used by tokunbo vehicle traders in the area is Kakara. Kakara (trade in) means to give an old or used item, (a vehicle) in part payment for a new one. ${ }^{5}$ The practice of kakara has recently gained ground because of the expansion recorded in tokunbo vehicles business in the country. Being fairly used one, the vehicle require constant change for at least every 3 to 4 years on average. Kakara became popular in the country since 2003, when large number of people began to replace their vehicles with new ones. The desperate need to change an old vehicle with the new (at least tokunbo) during the period was due to the enormous income acquired as a result of Obasanjo's monetization policy. Since then kakara continued to be an important strategy used by tokunbo vehicle traders to attract more customers. As a marketing strategy, kakara not only add more weight to the tokunbo businessmen by displaying various used vehicles acquired through it, but also serve as stimulus for profit making. Many traders claimed having a lot of profit from the vehicles obtained through kakara than the imported tokunbos. In fact, some of them even specialized in the selling of these used vehicles and are highly seen as most successful tokunbo businessmen.

The way kakara is done is to get somebody trusted, who is also acquainted with tokunbo vehicle business, so as to serve as intermediary. In some cases the buyer deal directly with the dealer after indicating interest in a particular make or model. The Dillali (middleman) is assigned to value the old vehicle. Usually, three categories of price are made and the dealer can choose any of the options depending on the mode of payment. Usually the first category is used since the buyer is not going to pay cash. Immediately after a few consultations the buyer hands down the remaining balance to the dillali or as the case may be-arrange on when to pay the remaining balance. In most cases kakara is done through credit arrangement. The use of kakara strategy developed out of the poor economic performance of Nigeria. It would be recalled that despite the euphoria of transition to civilian rule, the country continue to be economically backward and in fact, one of the 20 poorest countries in the world with more than $70 \%$ of Nigerians living below $1 \$$ in a day (UNDP, 2009). Given this condition, even to buy tokunbo vehicle appears hard to the middle-income earners. Kakara therefore became the easiest way for one to replace his vehicle since there is no provision for one to dispose his old vehicle and be replaced with at least tokunbo. In this case, the owner of the old vehicle is only left with one option for the disposal of an aged vehicle, which is to go for kakara. Those vehicles (acquired through kakara) that remain useful are displayed in the market while those that are nearly broken are taken to waste market known as kasuwar gongoni and dismantled as spare parts. The Kasuwar gongoni also forms another profitable economic venture dominated mostly by the Hausas and Yorubas petty traders in different parts of Northern Nigeria. ${ }^{28-30}$

The major advantage of kakara is that it quickly provides the owner of an old broken vehicle with an alternative to dispose it and get a fairly tokunbo one in its place with ease. This has contributed 
significantly to the quick speed of tokunbo vehicles market as new centers were opened to accommodate the increasing buyers. This also helps to further explain the traders' ingenuity in creating a business strategy to contain a given social problem. Another way in which kakara strategy facilitates tokunbo vehicle business in Nigeria is that it creates opportunity for even those who could not afford tokunbo vehicles to buy 'used vehicles'. The economic hardship in the country brought about by economic meltdown since 2008 in particular, have consolidated the expansion of used vehicle market in the country. Most of those interviewed have attributed the speed expansion of used vehicles tabajiki market during the period to the economic hardship. Researcher's observation reveals that in every ten tokunbo vehicles sold in Sokoto, Kebbi and Katsina, three were used vehicles Tabajiki. $^{30,31}$

Another related strategy similar to kakara which is used by the tokunbo vehicle traders is Jagwal (trade on). Whereas, in Kakara (trade in) the owner of the disposed vehicle pays the remaining balance to the seller to obtain another one, in the case of Jagwal, the reverse is the case. The owner of the vehicle, for one reason or the other decides to change his vehicle with a lower version and get in turn the balance over the price of the one he is buying. Jagwal is very rare in tokunbo vehicles market and it is more pronounced only where an owner is in daring need of money.

\section{The use of Tokunbo vehicle marketers association}

Tokunbo vehicles marketers in Nigeria have an umbrella association called the Motor Dealers Association of Nigeria (MDAN). The main function of the association is to regulate the second-hand automobile market and protect its members from harassment from security organizations especially customs agent. The association has its chapters in every state in the country. The various chapters operate independently from the national body except in some special cases that seem to threaten their collective interest. This is clear when considering the fact that since 1999, the association succeeded in persuading the custom authorities to stop harassing their members especially in their various vehicles shades. Since then, Custom and other law enforcement agencies do not raid second-hand vehicles smuggled into the country. Instead customs officials confiscate vehicles without valid customs papers from hapless commuters on the highway. This is an indication that the association (MDAN) provides adequate protection for its members. The protection is of course secured through negotiations and financial inducements to the relevant security agencies. ${ }^{32}$

An intending tokunbo vehicle seller must belong to the (MDAN) association in addition to his many years of experience in the business. The association also seeks to internalize in its members the value of cooperation. ${ }^{33}$ Members are always expected to protect one another's interest and to see one another as partner in progress for profit making and the protection of the trade from the 'unfavorable government policies'. Since majority of tokunbo vehicles in the area are brought from Cotonou, this means that the traders have to device ways of protecting the members from harassment. This they did through lobbying and bribing. The association lobby government against policies that may be inimical to their business. In fact, one of the association's outstanding achievements through lobbying was to stop the custom from impounding tokunbo vehicles from their shops. The former chairman of the Association Sokoto branch claimed that, they had been able to achieve this through representation to Comptroller General of Custom. ${ }^{34}$ (Interview, February, 2013). However, in spite of the association's strong hold on its members, wealthy individuals, mostly politicians, engage in tokunbo vehicles marketing without having to go through the association's protocols. This however, may likely change since the New Automobile Policy requires that all vehicle dealers and importers for sale to the public shall be licensed by the National Automobile Council (NAC) of Nigeria. ${ }^{35}$ How this would change the face of tokunbo vehicles business in the country depends on government commitment and sincerity in dealing with the menace of smuggling of such vehicles into the country.

\section{Conclusion}

Two major conclusions could be derived from the discussion contained in this paper; first, the trade in second-hand or tokunbo vehicles in northern Nigeria developed out of the economic problems that affected the automobile industry in the 1980s; secondly, the indigenous automobile traders began to use opportunity created by the availability and affordability of tokunbo vehicle market to consolidate their position thereby contributing to the economic development of Nigeria. What we can understand from this paper is that Nigerians like other people are economically wise enough to proper solutions to economic challenges. The marketing strategy used by the traders in form of Kakara and Jagwal among several others provides an avenue for the expansion of tokunbo or second-hand vehicle market. New economic activities sprung up to absorb the rising challenges in the market brought about by wrecking vehicles. Thus, kasuwar tabajiki 'used vehicles market' and kasuwar gongoni 'waste market' became an easy ground for thousands of people to earn a living. The New Automobile Policy formulated in 2014 and reinvented in 2016 was received with mix reactions by many Nigerians. It appears that the government was eager to restrict the natural flow of the cars through its land borders without providing an alternative. How the policy affects the indigenous automobile businessmen in Nigeria is left to be seen. What is obvious however is that, experience has shown that the more prohibition measures on tokunbo vehicles the more profitable and desire of the smugglers to bring such vehicles. Alternatively, since the Nigerian automobile market is large enough to accommodate huge number of tokunbo vehicles, there is no need for restriction. The government only needs to tackle the issue of smuggling and corruption in the border areas. The question is no more on whether or not the tokunbo vehicle business is economically important to the nation's economy. The proliferation of tokunbo vehicle business over the span of four decades has already proved that. All that government needs to do is to be holistic and gradual in its approach.

\section{Acknowledgments}

None.

\section{Conflicts of interest}

The author declares no conflicts of interest.

\section{Funding}

None.

\section{References}

1. United Nations Development Programme, UNDP. Human Development Report: Nigeria, 2008-2009. Abuja: UNDP; 2009.

2. Omobowale AO. The Tokunbo Phenomenon and Second-hand Economy in Nigeria. New York: Africa Development, Peter Lang; 2013. 
3. Asiwaju AI. Boundaries and African Integration: Essays in Comparative History and Policy Analysis. Lagos: Panaf publishers; 2003.

4. Asiwaju AI. West African transformations: Comparative impacts of French and British Colonialism. Lagos. 2001.

5. Kamusun Hausa. Published by Centre for Hausa study, Bayero University, Kano. 2006.

6. Alhaji Aminu Bayero Gwandu. Al-Umma Motors. Gawon Nama. 2013.

7. Olukoju A. Transportation in Colonial West Africa. In: Ogunremi GO, Faluyi EK, editors. An Economic History of West Africa since 1750. Ibadan: Rex Charles; 1996.

8. Bashir IL. The Politics of Industrilization in Kano: industries, incentives and indigenous entrepreneurs, 1950-1980. PhD thesis, Boston. 1983.

9. Bako A. Sabon-Gari Kano: A history of Immigrants and Inter-group Relations in the 20th Century. Sokoto: Usmanu Danfodiyo University Press; 2006.

10. Federal Republic of Nigeria. Review of the Nigeria Economy. Federal Office of Statistics. 1998.

11. Federal republic of Nigeria. Second and final Report of the wages and salaries review commission, 1970-1971, Federal ministry of information, Printing division, Lagos; 1971.

12. Federal republic of Nigeria. Second national development plan, lagos federal ministry of Information, 1970-1974. 1975.

13. Madugu YU. Origin and development of kano state transport corporation (Kano line) 1951-2007: An historical overview. Sokoto Journal of History. 2013:2.

14. Alhaji balarabe mainasara, 87 Years, National standard motors, Dogondaji House, Sokoto, Kwamberu Area, Sokoto, 05-10-2013.

15. Alhaji Malamin Dan Kure, 52 Years, Tokunbo Vehicles Trader, GidanKanawa Area, Sokoto, 15-05-2012

16. Falola T, MM Heaton. A history of Nigeria, University of Texas and Austin, Cambridge University Press. 2008.

17. Olukoshi AO. West Africa's political economy in the next millennium: retrospect and prospect, Codesria, Dakar. 2003.

18. Olukoshi AO. The policies of structural adjustment in Nigeria Heinemann, Ibadan. 1993.
19. The World Bank. Adjustment in Africa: lessons from the contemporary case studies. Washington DC; 1992.

20. World Bank. Trends in developing economies. Washington DC, USA; 1991.

21. Bangura Y. The Recession and workers struggle in the vehicle assembly plants: a case study of Steyr -Nigeria'. In: Olukoshi A, editor. Crisis and Adjustment in the Nigerian Economy, Lagos: JAD Publishers; 1991.

22. Abdulkadir MS. Structuring, struggling and surviving economic depression in Northern Nigeria: the 1930s as preview of the present Ninth Inaugural lecture, BUK; 2004.

23. Barkindo BM. Smuggling of second-hand or tokunbo vehicles in to Nigeria: causes, nature and perspectives for solution'. In: Barkindo BM, Lipede A, editors. Human Trafficking and Economic Crimes across Nigeria's International Borders, Spectrum, Ibadan. 2007.

24. National Automotive Centre. Brief on the centre submitted to the minister of industries. 2003.

25. Alhaji Sani Gala, Illela, Nigerian, 37 Years, Tokunbo vehicle Trader, Zongou, Cotonou, Saturday, 2013.

26. Alhaji Isuhu Sule, Nigerien, 53 Years, Tokunbo vehicle Trader, Zongou, Cotonou, Saturday, 2013.

27. Omowen \& Dirk Van den. 2009. 48 p.

28. CBN. Economic and financial review. 1983;21(1).

29. CBN. Bullion: a publication of Central Bank of Nigeria. 1986;10(2)

30. Field Notes. May, 2014.

31. Gewarld J. The speed of change: motor vehicles and people in Africa, 1890-2000, Brill. 2009

32. Federal office of statistics. Economic and Social Statistics Bulletin, Lagos. 1985.

33. Omobowale AO. The Tokunbo Phenomenon and Second-hand Economy in Nigeria, Africa Development, Peter Lang, New York. 2013.

34. Interview, February, 2013

35. FGN. Circular NO. BD/FP/DO/09/1/224/ 'Revised Fiscal Measures for Automotive Industry'. 2014. 